\title{
LUT
}

Lappeenranta

University of Technology

\section{Working capital management in the Russian automotive industry supply chain}

Pirttilä Miia, Virolainen Veli Matti, Lind Lotta, Kärri Timo

This is a Post-print version of a publication

published by Elsevier

in International Journal of Production Economics

DOI: $\quad 10.1016 / j . i j p e .2019 .08 .009$

Copyright of the original publication: () 2019 Elsevier B.V.

Please cite the publication as follows:

Pirttilä M. Virolainen V.M., Lind L., Kärri T. (2019). Working capital management in the Russian automotive industry supply chain. International Journal of Production Economics. DOI: 10.1016/j. ijpe.2019.08.009 
WORKING CAPITAL MANAGEMENT IN THE RUSSIAN AUTOMOTIVE INDUSTRY SUPPLY CHAIN

\author{
M. Pirttilä ${ }^{1}$, V.M. Virolainen ${ }^{(1}$, L. Lind ${ }^{(2}$, T. Kärrii ${ }^{(1}$ \\ ${ }^{(1}$ LUT University, P.O. Box 20, 53851 Lappeenranta, Finland \\ ${ }^{2)}$ ABB Oy, P.O. Box 184, 00381 Helsinki, Finland
}




\begin{abstract}
Companies must successfully finance their supply chains if they are to maintain their competitive advantage. Specifically, asset management in a supply chain is an essential component of improving one's financial stance. This study examines operational working capital management in the Russian automotive supply chain using the transaction cost theory (TCE) perspective. It considers working capital management (WCM) models with financial supply chain analysis using cash conversion cycles (CCC) and return on assets (ROA) as measurements. Companies operating with efficient WCM models are usually the leaders and the most powerful actors in the supply chain. Overall, according to our analysis long accounts payable payment period are prevalent, inventory levels high and CCCs short. Further, the most profitable firms are those that pay their suppliers promptly. The WCM models based on the data of this study may contribute to deliberate strategies and choices regarding the optimal governance structures of supply chains.
\end{abstract}

Keywords: supply chain management, automotive industry, working capital, transaction cost theory 


\section{Introduction}

Globally, the automotive industry is seen as a trailblazer in the manufacturing industry and in the field of supply chain management. The scientific basis for studies of supply chains is transaction cost theory (TCE), and mainstream research on the topic has concentrated on the Western automotive industry-here, the most common operating model is close collaboration with a supply network via relationships based on trust. This study concentrates on the Russian automotive industry and the financial aspects of its supply chain.

This study continues the research related to TCE and especially one of its features (i.e., operational working capital management $[\mathrm{WCM}])$ in the inter-organizational supply chain context. While earlier studies on this subject have been conducted on the Western automotive industry (e.g., Brandenburg, 2015; Lind et al., 2017 \& 2012; Viskari et al., 2012), this study focuses on the Russian automotive industry. It provides a more comprehensive analysis of the issues in WCM through secondary data. The results of the researchers' previous papers clearly show that the Russian automotive industry is managing their working capital more effectively than the Western one (Virolainen et al., 2015; 2016). This is an astounding result that needs to be investigated and explained more rigorously.

The Russian economy is a very challenging environment—governance and management in Russia are based on different types of social and individual networks and informal relationships. The automotive sector also has several unique characteristics that differ significantly from the typical supply chain in the West, including the localization rate for components sourced within Russia or the Customs Union. In addition, many companies in the automotive industry lack modern and digitalized manufacturing and design technologies. Capital investments in production, marketing, and innovation activities are limited, and the Russian government plays an essential role in the industry by establishing policies to protect the automotive industry of Russian origin. Finally, the country's current political circumstances influence the possibilities to create networks of close cooperation with international value chains.

\section{Objectives}

The goal of this study is to investigate companies' economic transactions from the supply chain perspective through WCM. In doing so, it examines the relevance of TCE for supporting WCM. WCM models are studied by using financial supply chain analysis (Lind et al., 2012). Companies operating with efficient WCM models are usually the leaders and the 
most powerful actors in the supply chain. According to earlier studies, powerful companies are able to influence their payment periods as well as the size of their inventories, allowing them to operate whilst investing less working capital (e.g., Farris and Hutchison, 2002). In this study, WCM models are approached using the cycle times of working capital-precisely, cash conversion cycles (CCC). Further, the study investigates model profitability using return on assets (ROA). While cycle times are concrete and controllable measurements-and therefore commonly used in business to determine inter-company transactions- they have a direct connection to TCE by indicating selected government structure. This study investigates the supply chain performance (mainly from the WCM point of view) of the Russian automotive industry. It analyzes local relational behavior within the automotive supply chain in Russia and makes comparisons with Western automotive supply chains. The results should help stakeholders to create informed strategies and choose the optimal governance structure for their supply chains.

\section{Literature Review}

This study addresses the financial elements of supply chains and links supply chain finance (SCF) to TCE. According to Kristofik et al. (2012), a financial supply chain is all about the movement of money along the chain. This study understands SCF from a holistic perspective that also focuses on trade credit and inventory (i.e., the operational working capital tied up in a supply chain) (Randall et al., 2009). Hence, in its broadest perspective, SCF concerns all supply chain objects: the flow of goods, information, and finance; processes; current and fixed assets; and the personnel involved in the supply chain (Hofmann, 2005). In short, this definition connects SCF with TCE.

The management of operational working capital as part of SCF requires balancing the reduction of capital that is already tied up, which increases profitability, and minimizing risks caused by a too-small amount of operational working capital (Marttonen et al., 2013). When financing and investing in working capital, actors tend to subscribe to one of three approaches: aggressive, moderate, or conservative (Brigham et al., 1999). They differ in the proportion of the long-term and short-term financing used as a source for permanent and temporary working capital, respectively. Moreover, these three approaches have different risk and profitability trade-offs. An aggressive investment approach, which entails the management of smaller holdings of cash, marketable securities, debtors, and inventories, should provide better performance by way of a higher rate of return, but it is more risky than 
the moderate and relaxed strategies - these approaches maintain larger holdings of inventory, debtors, cash, and marketable securities.

In terms of CCC, an aggressive investment strategy would mean that accounts payable are increased and investments in inventory and accounts receivable are decreased; this should shorten the CCC. In contrast, a conservative investment approach to WCM would result in a prolonged $\mathrm{CCC}$, as accounts receivable and inventory are increased and accounts payable are decreased. Previous studies prefer to confirm that aggressive WCM is associated with higher profitability (e.g., Shin and Soenen, 1998; Deloof, 2003; Lazaridis and Tryfonidis, 2006).

TCE is an economic theory that provides an analytical framework for investigating the governance structure of contractual relations within a supply chain (Coase, 1937; Williamson, 1979). According to Williamson (1981), a transaction cost occurs when a good or a service is transferred across a technologically separable interface. Therefore, transaction costs arise every time a product or service transfers from one stage to another-in other words, a transaction cost is the cost of making an economic exchange.

TCE suggests that the costs and difficulties associated with market transactions sometimes favor hierarchies (or in-house production) and sometimes markets as an economic governance structure (Williamson, 1981). Moreover, an intermediate mechanism has emerged, labeled "hybrid" or "relational," between these two extremes as a new governance structure (Williamson, 1981; Blomqvist et al., 2002). Gereffi et al. (2005) argue that supply chains can fall into five different governance structures depending on the relative levels of three dimensions: complexity of transaction, ability to codify knowledge, and capabilities in the supply base. The authors suggest that these three dimensions result in a typology that consists of five supply chain governance structures: market, modular, relational, captive, and hierarchy.

The key attributes of TCE are asset specificity, uncertainty, and frequency. Asset specificity means that a firm is tied to transaction-specific assets, which can be redeployed to alternative uses and users only at a loss of productive value. Terms of payments can be considered to be transaction-specific because they are dependent upon existing business relationships. Thus, asset specificity may create a bilateral dependency and lock-in situation for buyers and suppliers (Williamson, 2008). Uncertainty arises from the inconsistent economic environment in which companies operate, and firms must adapt to changing circumstances. Uncertainty has a direct impact on terms of payments - the frequency of uncertainty and asset specificity 
affects reputation and setup costs; moreover, varying net effects may arise depending on special arrangements between actors.

Governance structures are described as series of attributes that differ in discrete structural ways. Markets and hierarchies are the polar modes to which hybrid (long-term) contracting can be related as an intermediate mode. Different values and combinations of these attributes give rise to adaptive strengths and weaknesses. Different governance structures also typify different power relations. According to Williamson (2008), the three leading styles of mediating the contractual interface for hybrid transactions are (1) muscular, (2) benign, and (3) credible. In the muscular approach, buyers use their negotiating power as well as often "use up" and discard their suppliers (Keith et al., 2015). The benign and credible approaches are collaborative-here, the power is more invisible and not the highest priority in relationship management.

The central tenet of TCE is that transactions will be handled such that they minimize the costs involved in carrying them out. The transactions in this study refer to finances committed to net WCM. In net WCM, the four elements of cash, debtors, stock, and creditors stand out as key problems, the management of which involves rigorous planning and resource commitment.

Grover and Malhotra (2003) state that TCE can be used to evaluate how various types of investments within firms can build long-term capabilities and what their impact is on performance. Investments that are specific to a relationship lock in the supplier and increase the costs of switching to another buyer. According to Garfamy (2012), the greater the level of asset specificity, the more an allied partner needs cooperation adaptability to modify the agreement rather than leave the partnership. In the case of a low level of asset specificity, the desire for cooperation adaptability diminishes and the need for exit flexibility increases. It is also difficult to completely eliminate uncertainty because the organization deals with customer orders, which are generated randomly. Demand uncertainty may force a firm to develop a closer relationship with its suppliers to better meet market requirements, or alternatively, to develop standardized products and have extra inventory to counter the uncertainty (Premkumar, 2000). Similarly, suppliers face uncertainty related to supplies; supply uncertainty can be caused by variations in lead time or product quality.

Some goods and services can be produced more efficiently if one of the parties invests in "transaction-specific" assets that cannot easily be put other uses if the buyer/supplier 
relationship breaks down. Asset specificity can take a variety of forms, including site or location specificity, where a buyer or seller locates its facilities next to the other to economize on inventory or transportation costs.

\section{Data and Methods}

\section{Empirical Setting and Data}

The empirical setting for this study is the Russian automotive industry. Governmental intervention is a crucial factor that has influenced the development of the automotive industry in Russia since it began to intervene in March 2005. The decision concerned introducing amendments to the customs tariff of the Russian Federation with respect to vehicle components imported for industrial assembly. Additionally, original equipment manufacturers (OEMs) were encouraged to invest in establishing and developing R\&D centers in Russia. Today, suppliers are still the weak link of the Russian automotive industry. Local suppliers need to develop their products to meet requirements for cost, quality, and technology (Ernst \& Young, 2017).

Figure 1 shows the demand for cars in Russia. The proportion of locally produced cars is high in comparison with imported cars - approximately three out of four cars that are sold are made in Russia. Demand peaked in 2012, with nearly three million cars sold. In 2014, the Russian economy entered a downturn that caused a dramatic decrease in demand for new cars. The Russian Federation allocated support to the automotive industry during the fourth quarter of 2014, especially for manufacturers of Russian origin. Thus, the sales volume of 2014 does not accurately reflect the beginning of the country's economic downturn.

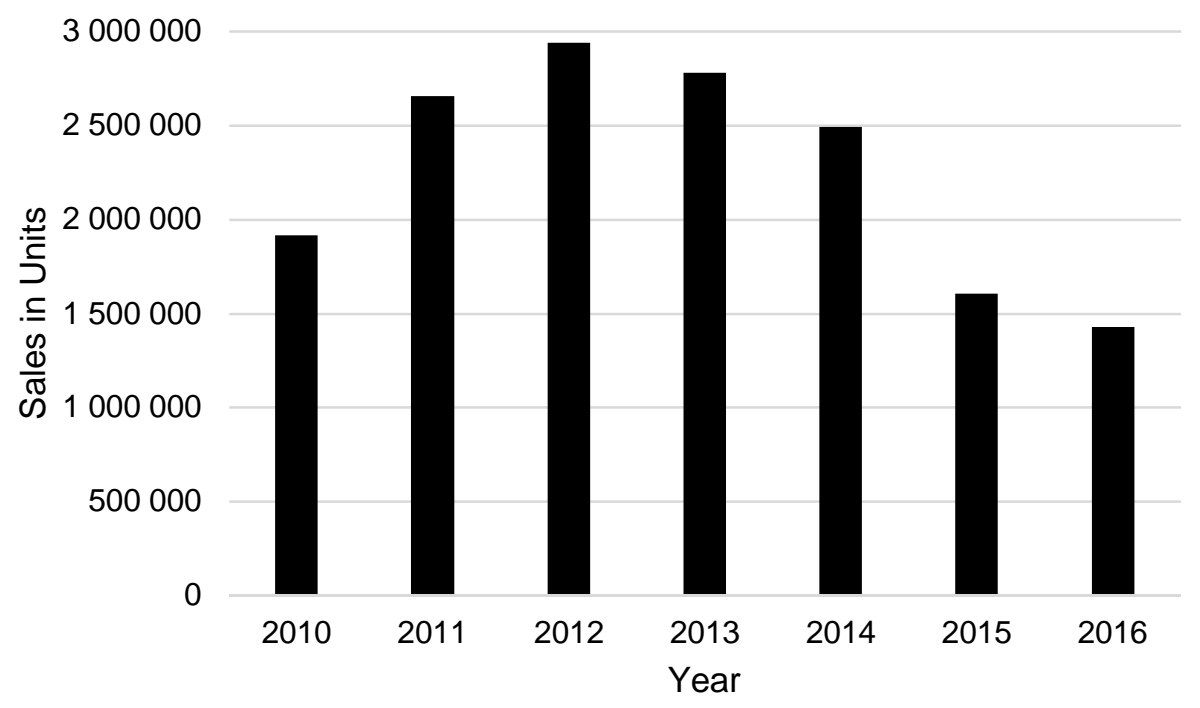


Figure 1. Retail sales of imported and locally produced vehicles in Russia from 2010-2016 (Source: Association of European Businesses, 2018)

This study collected data on the Russian automotive industry from the Amadeus database. The following industry classifications were used: 2920 - manufacture of bodies (coachwork) for motor vehicles and manufacture of trailers and semi-trailers; 2931-manufacture of electrical and electronic equipment for motor vehicles; 2932-manufacture of other parts and accessories for motor vehicle form class suppliers; 2910-manufacture of motor vehicle form class manufacturers; and 4511 - sale of cars and light motor vehicles (referred to in the text, tables, and figures as "dealers and distributors"). These definitions led to a sample comprised of 20,459 companies. Unfortunately, companies with figures for inventory, accounts receivable, and accounts payable were limited. The study used the following inclusion criterion: each firm must have a positive, but no longer than the 365-day cycle time of inventory, accounts receivable, and accounts payable. In the data-cleaning step, each firm's days inventory outstanding (DIO), days accounts receivable outstanding (DSO), days accounts payable outstanding (DPO), operating revenue, and total assets had to exist for at least for four years during the period of 2010-2016. After these steps, the sample totaled 2,330 companies. The data were collected in Winter 2017 and supplemented by Avtovaz and Kamaz's figures from 2016. Table 1 shows the descriptive statistics of the sample.

Table 1. Descriptive statistics of the sample

\begin{tabular}{|c|c|c|c|c|c|c|}
\hline & $\mathrm{n}$ & $\begin{array}{c}\text { Sales } \\
2016 \\
\text { (M RUB) } \\
\text { MAX }\end{array}$ & $\begin{array}{c}\text { Sales } \\
2016 \\
\text { (M RUB) } \\
\text { MIN }\end{array}$ & $\begin{array}{c}\text { Total } \\
\text { assets } \\
2016 \\
\text { (M RUB) } \\
\text { MAX }\end{array}$ & $\begin{array}{c}\text { Total } \\
\text { assets } \\
2016 \\
\text { (M RUB) } \\
\text { MIN }\end{array}$ & $\begin{array}{c}\text { ROA } \\
2016 \\
(\%) \\
\text { average }\end{array}$ \\
\hline Bodies for motor vehicles & 52 & 6622 & 2.63 & 4212 & 2.581 & $10 \%$ \\
\hline Electrical and electronic equipment & 169 & 13038 & 0.19 & 6854 & 0.263 & $11 \%$ \\
\hline Other parts and accessories & 103 & 8276 & 1.12 & 8409 & 0.014 & $12 \%$ \\
\hline Manufacture of motor vehicles & 158 & 191108 & 0.01 & 133473 & 0.202 & $7 \%$ \\
\hline Dealers and distributors & 1845 & 277539 & 0.002 & 41855 & 0.001 & $-1 \%$ \\
\hline
\end{tabular}

Figure 2 shows the balance sheet structures in different stages of the Russian automotive industry supply chain. The amount of current assets that includes inventory and accounts receivable ranges from $70-84 \%$ of the total assets gained through the supply chain. The dealers and distributors have invested the least in fixed assets. The current liabilities including accounts payable range from $55-70 \%$ except the current liabilities of class dealers and distributors is balancing negative equity. 

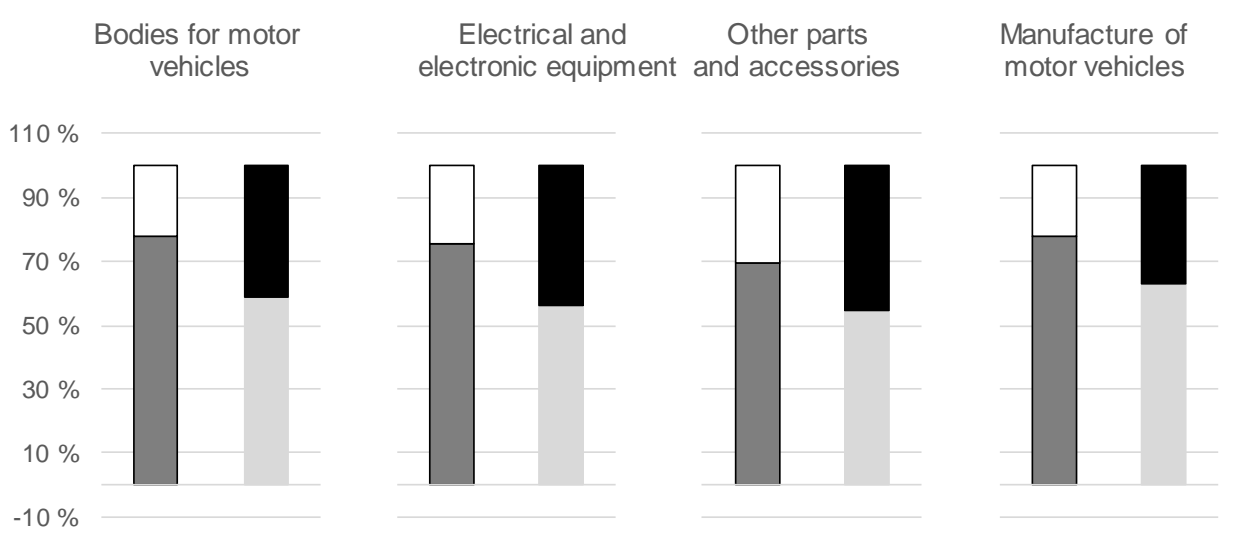

Dealers and distributors

\section{Current assets $\quad$ GFixed assets $\quad$ Current liabilities}

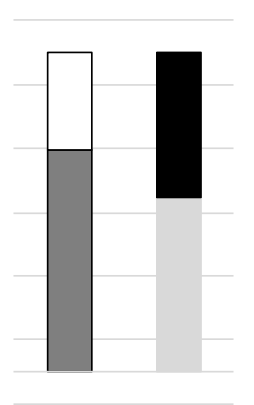

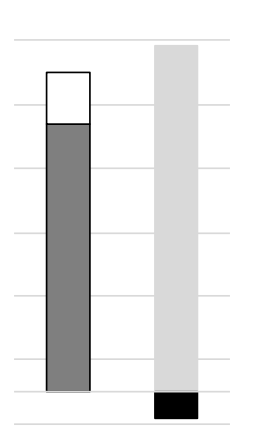

Equity + Long term liabilities

Figure 2. Balance sheet structure of the Russian automotive supply chain, 2010-2016

\section{Methods}

CCC (Richards and Laughlin, 1980) is used to measure and control the effectiveness of

WCM based on relative ratios. CCC indicates the number of days the company has funds tied up in working capital. There are slight differences in how researchers calculated CCC in the existing literature. In this study, the calculation follows Shin and Soenen's (1998) definition:

$$
\mathrm{CCC}=D I O+D S O-D P O=\frac{\text { inventory }+ \text { accounts receivable }- \text { accounts payable }}{\text { sales }} \cdot 365
$$

This study uses the financial supply chain analysis method (Lind et al., 2012). Its results are arithmetic means of DIO, DSO, DPO, and CCC. Here, a company's CCC and its components are calculated as an average of the years 2010-2016.

The WCM models of companies were divided into three categories based on the components of CCC: aggressive (A), moderate (M), and conservative (C). A company's inventory and accounts receivable management policies are aggressive when their DIO and DSO are less than or equal to the 25 th percentile. Those with values that are greater than the 75 th percentile are considered to follow a conservative policy. The rest of the companies follow moderate policies concerning the management of inventories and accounts receivable. A company's accounts payable policy is considered to be aggressive when the DPO exceeds the 75 th percentile and conservative when it is less than or equal to the 25 th percentile; the rest of the companies follow a moderate policy. This leads to 27 WCM models. Previous studies by Jędrzejczak-Gas (2017) and Lind et al. (2017) considered companies' WCM strategies with a similar approach. Lind et al. (2017) studied WCM strategies as a combination of the management of material and financial flows of working capital; thus, they combined the trade 
credit components and measured the efficiency of the financial flow as a difference between the DSO and DPO. The present study considered applying the same definition, but it seemed to lead to unrealistic results. The value of DSO minus DPO- the measurement of trade credit policy-is negative for $66.7 \%$ of the companies included in the sample. This study rejects the suggestion that companies operating in the Russian automotive supply chain heavily follow aggressive trade credit policies. However, there is no universal definition of how many days make something conservative or aggressive for the cycle time of working capital components. It should be noted that reference values impact the quality of the cycle time of a company's working capital components.

The Wilcoxon signed-rank test is used to analyze the significance of yearly differences in $\mathrm{CCC}$ and its components for class level; it is also used to confirm that WCM practices in the Russian automotive industry differ from those used in the West. This latter analysis is done using firm-level figures. The Kruskal-Wallis $\mathrm{H}$ test is used to determine if there are statistically significant differences in ROA between WCM models.

\section{Results and Analysis}

The CCC and its components were calculated for 2010-2016 to analyze WCM in the supply chain of the Russian automotive industry. Figure 3 presents a histogram based on the average CCC of the sample; the histogram is formed by considering the meaning of CCC. A total of 317 companies representing $13.6 \%$ of sample are able to operate at negative CCC. This is a unique feature of the Russian automotive industry that has not been widely reported in previous literature. The most globally well-known companies that are able to operate at negative CCC are in the information and communications technology (ICT) industry: Apple and Dell. Most of the positive CCC observations last for 40-59 days. To sum up the histogram, 734 companies operate on a positive $\mathrm{CCC}$ that is at the most one month in length, 959 companies' CCC is between a month and three months, and 311 companies have a CCC in excess of three months. 


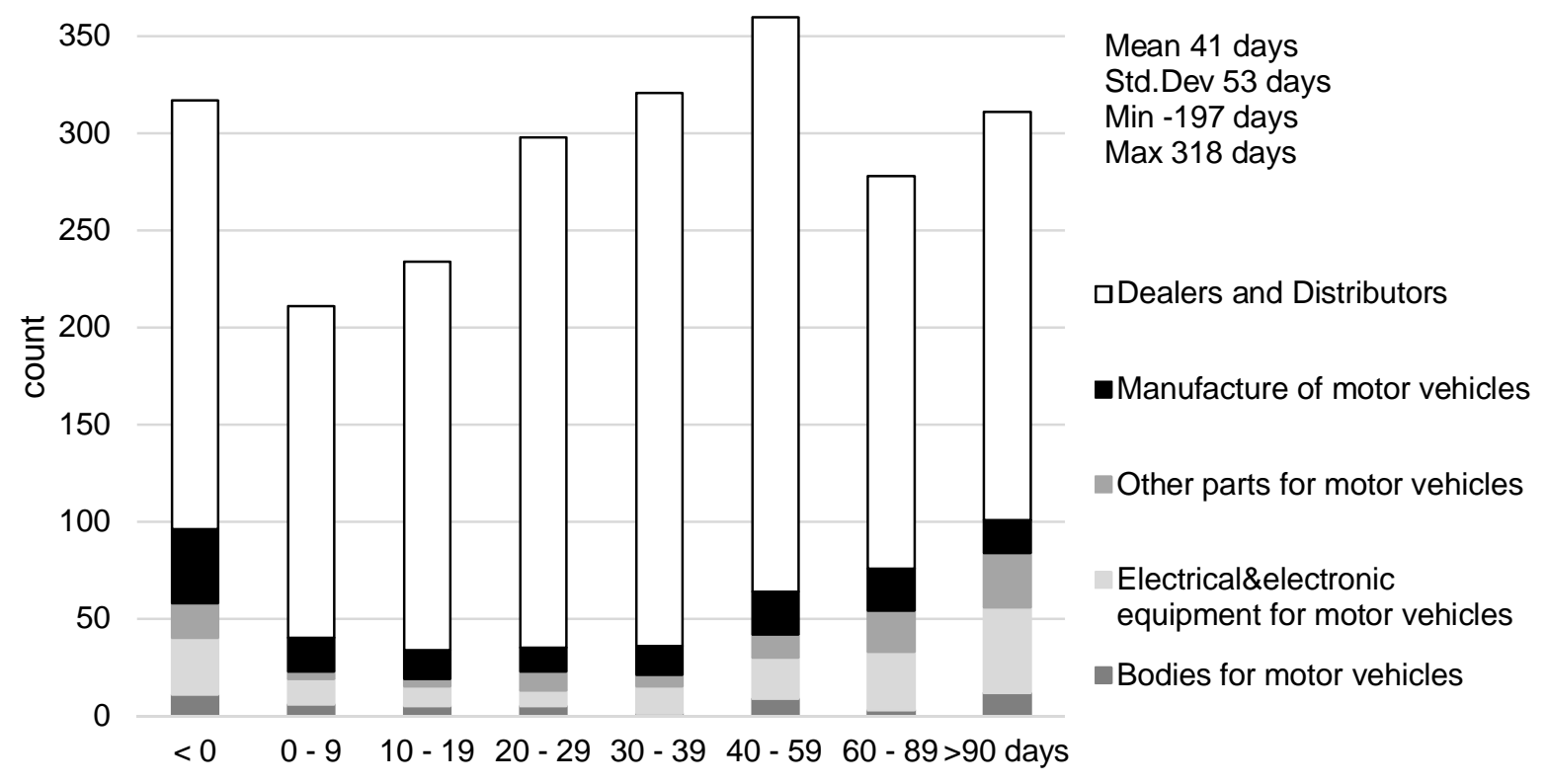

Figure 3. The distribution of CCC, 2010-2016

Figure 4 shows the results for the whole industry, dealers and distributors, car manufacturers, and suppliers; that is further divided into three subclasses.
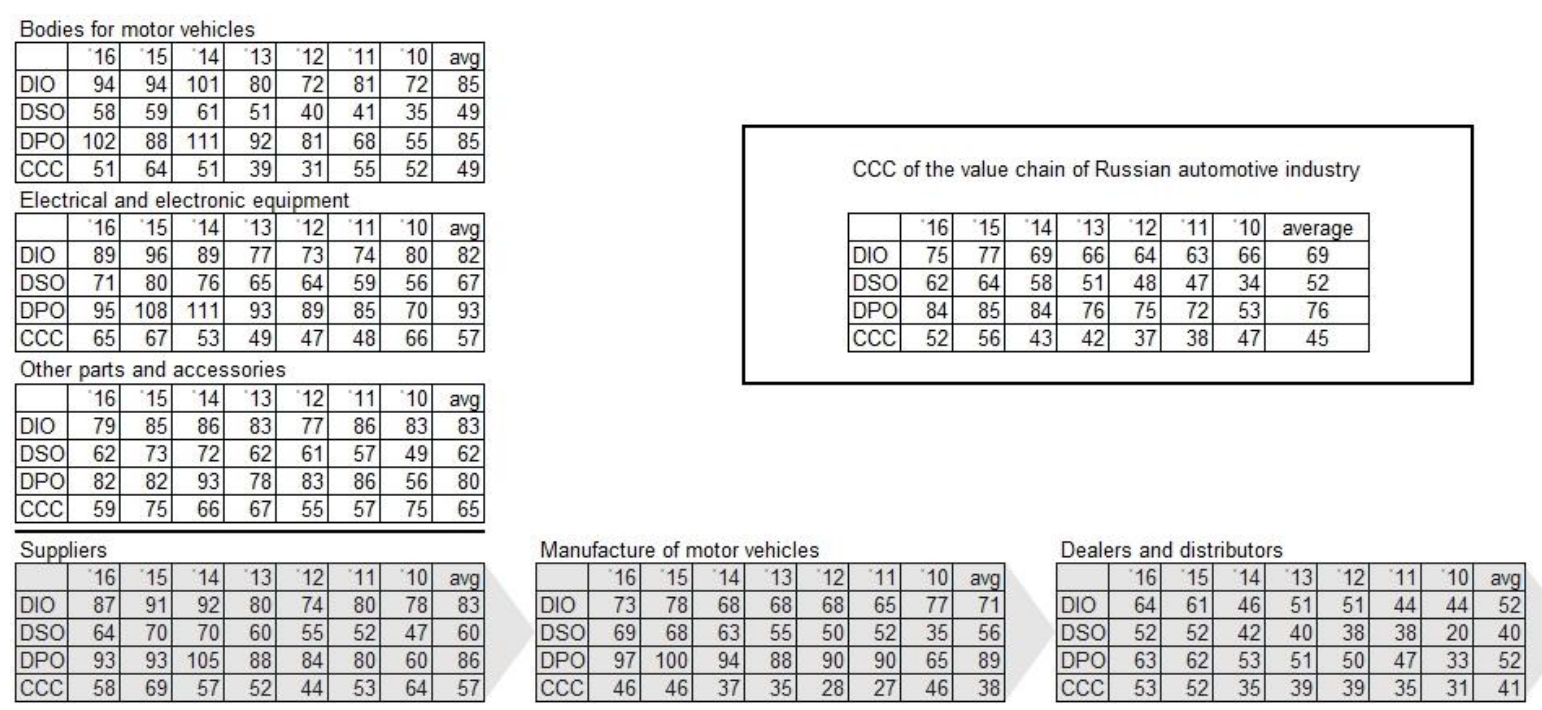

Figure 4. The cycle times of working capital in the supply chain of the Russian automotive industry

The results in Figure 4 show that the supply chain of the Russian automotive industry ties up working capital in the supply chain for an average of 45 days. The trend of CCC has been prolongation - the average value is shorter than the value for the year 2016. Only the subclass "other parts and accessories" is an exception-its average CCC is longer than its value for the year 2016. In all stages, the values of the yearly CCC during the observation period fluctuate; this indicates that forecasting tied-up working capital by sales is unreliable. This study 
assumes that the ecosystem around the automotive industry's supply chain affects this fluctuation; further, it has changed so rapidly that companies have not had time to react to the new business environment. Especially, the normal mode of trade credit management in Russia supports short CCC. Car manufacturers operate with shorter CCC in Russia than in the West, and the DSOs of Russian car manufacturers are about half that of Western European car manufacturers. They do not seem to operate as a bank by offering financing solutions for end-customers who are buying the vehicles they manufacture, as is the case in with Western car manufacturers. For example, for the Volkswagen Group, financial services are seen as an important part of its business (Volkswagen Group, 2009, p. 36). Besides this, it is a profitable business for them. The cycle times of Russian automotive industry companies' inventories are remarkably long; this implies high safety stock levels, which might be a consequence of high uncertainty.

A few previous articles consider WCM in the context of the Western European automotive industry. The results of this study are comparable with studies by Lind et al $(2017 ; 2012)$. Brandenburg (2015) follows a slightly different research frame; here, the ratio of the companies included in the class "affiliates" is large. Affiliates are subsidiary companies of car manufacturers; however, in the present study, subsidiary companies of car manufacturers operating in Russia are considered to be manufacturers-Lind et al. (2017; 2012) do not include class affiliates in their studies. Brandenburg (2015) focuses on the development of the cost of goods sold, using this to calculate DIO and DPO, yielding longer time spans than those found in this study. However, it is difficult to define the exact impact on the value of CCC. Furthermore, this study has a large sample; Lind et al.'s $(2012 ; 2017)$ and Brandenburg's (2015) samples are relatively small and examine companies' relationships, which is not included in this study. Table 2 shows the results of this study and of Lind et al.'s $(2017$; 2012) studies. 
Table 2. The CCCs of the Western European automotive industry and the Russian automotive industry

\begin{tabular}{|c|c|c|c|c|}
\hline Source & Lind et al. (2017) & Lind et al. (2017) & Lind et al. (2012) & This study \\
\hline Period & years 2006-2010 & years 2011-2015 & years 2006-2008 & years 2010-2016 \\
\hline Sample size & 29 & 29 & 46 & 2327 \\
\hline suppliers & 24 & 24 & 30 & 324 \\
\hline manufacturers & 5 & 5 & 9 & 158 \\
\hline dealers & & & 7 & 1845 \\
\hline $\begin{array}{l}\text { WCM indicators } \\
\text { average of CCC }\end{array}$ & 87 & 71 & 65 & 45 \\
\hline median of CCC & 76 & 72 & 70 & 33 \\
\hline
\end{tabular}

It seems that WCM is more efficient in the supply chain of the Russian automotive industry - the average and median CCC of the supply chain are shorter in Russia. The Wilcoxon signed-rank test confirms that the results are statistically significant (test results reported in Appendix 1). The periods of the datasets differ, and it can be seen that trends in Western Europe are shorter in terms of CCC; further, this study shows that the development of CCC in the Russian automotive industry is opposite to that of Western Europe.

Brandenburg's (2015) results are more in line with the results of this research, but the research frame differs, as mentioned above. Based on Table 2 and Brandenburg's (2015) results, it seems that dealers, distributors, and affiliates shorten the CCC of the Western European automotive industry. In Russia, the CCC of car manufacturers is the shortest. Figure 4 illustrates that the supply chain of the Russian automotive industry has established an aggressive trade credit policy. The cycle time of the accounts receivable (DSO) is shortened when factoring is used. Because the use of factoring in Russia is not common (Virolainen et al., 2015), the results of the analysis indicate that powerful companies use their power of negation, making the CCC of the supply chain shorter than that of Western Europe. In each year during the observation period, the average DSO is shorter than the DPO. However, companies operating in supply chains do not seem to be squeezing one another. The DSO of suppliers is shorter than the DPO of car manufacturers-similarly, the DSO of car manufacturers is shorter than DPO of dealers and distributors. In the supply chain context, a supplier's DSO is equal to its buyer's DPO. In some quarters, operating in the ecosystem surrounding the supply chain requires offering buyer-friendly payment terms to customers. When the figures of each class are looked at separately, the figures from the suppliers reveal a fundamental change in CCC components' cycle times between 2013 and 2014. The cycle 
time of inventories, accounts receivable, and accounts payable lengthened by at least 10 days. The Wilcoxon signed-rank test indicates that this increase in cycle times is statistically significant (test results reported in Appendix 2). The CCC has not lengthened as much; however, the lengthening of the DPOs offset the increase in the DSOs and the DIOs.

The question of the valuation of assets is an important one to consider. There is no certainty of new guidelines concerning the valuation of operational working capital components that would explain such an increase. Based on the DIO values, it seems that suppliers are holding the supply chain inventories. A specific feature of car manufacturers is the lengthening of the cycle time of accounts receivable; beginning in 2013, they finance more and more for their customers. Dealers and distributors act similarly; their cycle time of accounts receivable also lengthened during the observation period. This study assumes that dealers and distributors do not offer credit to their end-customers, but they do so for some car-financing institutes that finance the end-customers' car purchasing. There is also a lengthening in the dealers' and distributors' DIOs. According to the results, both car manufacturers and dealers and distributors carry safety stock to avoid shortages and minimize stock-out costs. The balance sheet gives information on the financial position of each company at a single point in time that might affect the results.

Table 3 presents the proportion of operational working capital items. Based on this information, this study concludes that the supply chain of the Russian automotive industry heavily relies on operational WCM. Operational working capital items cover around half the assets of each class. Earlier studies found that current assets equaled half the total assets (i.e., Haitman and Jyan, 2015). This study suggests that the proportion of current assets is even more (see Fig. 2). It still seems that no companies manage their operational working capital in a holistic manner.

Table 3. The average proportion of working capital items from current assets and liabilities

\begin{tabular}{lrr} 
& $\begin{array}{c}\text { (inventories + accounts } \\
\text { receivable) / current assets }\end{array}$ & $\begin{array}{r}\text { accounts payable / } \\
\text { current liabilities }\end{array}$ \\
\hline Bodies for motor vehicles & $84 \%$ & $84 \%$ \\
\hline Electrical and electronic equipment & $85 \%$ & $78 \%$ \\
\hline Other parts and accessories & $84 \%$ & $69 \%$ \\
\hline Manufacture of motor vehicles & $78 \%$ & $78 \%$ \\
\hline Dealers and distributors & $80 \%$ & $64 \%$ \\
\hline Total industry & $82 \%$ & $74 \%$ \\
\hline
\end{tabular}


The results of the study of WCM models are collected in Table 4. The first letter refers to the inventory model, the second to the accounts receivable model, and the third to the accounts payable model. $72.9 \%$ of the sample of this study follow the WCM models in the top 10 (see Table 4). The most popular model is MMM; here, the company's average DIO, DSO, and DPO are neither aggressive nor conservative in comparison with the reference values. The strength of the MMM model is mainly the result of the limits placed on categories A, M, and C: $50 \%$ of the companies are in the moderate category. Previous literature underlines that profitable companies pay their accounts payable quickly (Deloof, 2003; Enqvist et al., 2012). This study confirms this; a profitable firm pays its suppliers quickly. The most profitable models are the ACC, ACM, CAC, MCC, and CCC; however, these five models are not in the top 10. Only stages dealers and distributors follow the CAC and MCC models.

Over the years, several companies have focused on decreasing their operational working capital by reducing their inventory, tightening their trade credit terms toward the downstream, and stretching payments toward the upstream. Often, they do this by focusing on each component of their working capital individually. Strategy AAA represents these actions: three dealers and distributors follow it in the present sample. The average ROA of these companies is $-5.9 \%$. Their CCC is negative as well. It seems that AAA is not the best WCM model if the target is to improve financial performance. Other popular strategies for companies with negative CCCs are MMA, AMM, and MCA (for a total of 142 firms). These WCM models are profitable, but they are far behind the most profitable models. 
Table 4. The WCM models with profitability in the supply chain

\begin{tabular}{|c|c|c|c|c|c|c|c|c|}
\hline $\begin{array}{r}\text { Popularity } \\
\text { order of } \\
\text { WCM } \\
\text { models }\end{array}$ & $\begin{array}{c}\text { Name of } \\
\text { model }\end{array}$ & $\begin{array}{r}\text { Amount of } \\
\text { companies } \\
\text { following }\end{array}$ & $\begin{array}{r}\% \text { of } \\
\text { mpanies } \\
\text { luded to } \\
\text { study }\end{array}$ & Suppliers & $\begin{array}{r}\text { Manufac- } \\
\text { ture of } \\
\text { motor } \\
\text { vehicles }\end{array}$ & $\begin{array}{r}\text { Dealers } \\
\text { and } \\
\text { distributors }\end{array}$ & ROA & $\begin{array}{r}\text { Profitability } \\
\text { order of } \\
\text { WCM } \\
\text { models }\end{array}$ \\
\hline 1 & MMM & 387 & $16.6 \%$ & 45 & 28 & 314 & $3.2 \%$ & 22 \\
\hline 2 & MAC & 170 & $7.3 \%$ & 2 & 2 & 166 & $3.8 \%$ & 19 \\
\hline 3 & MAM & 165 & $7.1 \%$ & 11 & 6 & 148 & $1.2 \%$ & 24 \\
\hline 4 & AMM & 164 & $7.0 \%$ & 17 & 9 & 138 & $4.5 \%$ & 18 \\
\hline 5 & CCA & 162 & $7.0 \%$ & 47 & 19 & 96 & $4.6 \%$ & 17 \\
\hline 6 & CMM & 148 & $6.4 \%$ & 35 & 15 & 98 & $5.8 \%$ & 11 \\
\hline 7 & AAC & 146 & $6.3 \%$ & 1 & 1 & 144 & $8.2 \%$ & 8 \\
\hline 8 & CMA & 121 & $5.2 \%$ & 37 & 19 & 65 & $3.4 \%$ & 20 \\
\hline 8 & MCA & 121 & $5.2 \%$ & 30 & 11 & 80 & $5.6 \%$ & 13 \\
\hline 10 & MMC & 113 & $4.8 \%$ & 7 & 1 & 105 & $4.7 \%$ & 15 \\
\hline 11 & $\mathrm{MCM}$ & 103 & $4.4 \%$ & 19 & 8 & 76 & $8.8 \%$ & 7 \\
\hline 12 & AMC & 101 & $4.3 \%$ & 1 & 3 & 97 & $4.6 \%$ & 16 \\
\hline 13 & MMA & 88 & $3.8 \%$ & 21 & 13 & 54 & $3.2 \%$ & 21 \\
\hline 14 & $\mathrm{CCM}$ & 71 & $3.0 \%$ & 19 & 4 & 48 & $8.0 \%$ & 9 \\
\hline 15 & $\mathrm{ACM}$ & 55 & $2.4 \%$ & 9 & 3 & 43 & $15.9 \%$ & 2 \\
\hline 16 & $\mathrm{ACA}$ & 40 & $1.7 \%$ & 2 & 6 & 32 & $9.2 \%$ & 6 \\
\hline 16 & AAM & 40 & $1.7 \%$ & 1 & 4 & 35 & $5.9 \%$ & 10 \\
\hline 18 & CAM & 30 & $1.3 \%$ & 5 & 1 & 24 & $4.9 \%$ & 14 \\
\hline 19 & AMA & 23 & $1.0 \%$ & 4 & 2 & 17 & $2.0 \%$ & 23 \\
\hline 20 & CMC & 18 & $0.8 \%$ & 5 & 0 & 13 & $5.7 \%$ & 12 \\
\hline 21 & CAA & 14 & $0.6 \%$ & 1 & 2 & 11 & $-2.9 \%$ & 25 \\
\hline 22 & ACC & 13 & $0.6 \%$ & 1 & 0 & 12 & $17.5 \%$ & 1 \\
\hline 23 & $\mathrm{CCC}$ & 11 & $0.5 \%$ & 3 & 0 & 8 & $9.9 \%$ & 5 \\
\hline 24 & MAA & 10 & $0.4 \%$ & 1 & 1 & 8 & $-4.1 \%$ & 26 \\
\hline 25 & CAC & 7 & $0.3 \%$ & 0 & 0 & 7 & $14.5 \%$ & 3 \\
\hline 26 & MCC & 6 & $0.3 \%$ & 0 & 0 & 6 & $13.7 \%$ & 4 \\
\hline 27 & $\mathrm{AAA}$ & 3 & $0.1 \%$ & 0 & 0 & 3 & $-5.9 \%$ & 27 \\
\hline
\end{tabular}

Note. First letter: inventory management model; second letter: accounts receivable management model; third letter: accounts payable management model; management models: aggressive (A), moderate (M), conservative (C)

A Kruskal-Wallis $\mathrm{H}$ test indicates a statistically significant difference in ROA between the different WCM models: $\chi^{2}(26)=92.085, \mathrm{p}=0.000$.

\section{Conclusions and Recommendations}

This study provides a deeper understanding of the interrelationships between TCE and WCM in a supply chain context. The automotive sector has been a forerunner in implementing new types of supply chain relationships. Specifically, this study used the TCE approach and WCM measurements to study the supply chain of the Russian automotive industry. The proposed 
theoretical approach is better able to describe these complex interdependencies than traditional supply chain practices. This study arrives at some insights into how the attributes of TCE affect the level of operational working capital tied up in a supply chain.

WCM analysis reveals that the analyzed companies have strong negotiation power in trade credit terms; they have managed to lengthen the cycle time of accounts payable to substantially longer timeframes than those offered to customers (i.e., the cycle time of accounts receivable). This can be considered as a reflection of relative power. This situation may also be caused by old habits developed during the communist era, when personal relations between company managers favored taking credit from suppliers (Virolainen et al., 2015).

Although the Russian supply chain is more systematic (the cycle time of accounts payable is long and the $\mathrm{CCC}$ is surprisingly short), managing working capital in terms of its various elements is different compared to Western supply chains. The possibility for end-customers to have an effect on the terms of payments is quite minor. Western supply chains are characterized by the dynamics provided by market mechanisms. A surprisingly high portion of the companies included in the sample could operate at negative $\mathrm{CCC}$ - this is atypical in the Western European automotive industry. Brandenburg (2016) did not mention this issue at all, and Lind et al. (2017) reported only one company that achieved negative CCC by closely integrating suppliers into its supply chain.

The results of this study suggest that the firms in the automotive industry in Russia do not manage their working capital in a collaborative manner. This is in line with earlier findings that a muscular approach dominates relations in Russia. WCM practices in Russia indicate the command economic traditions of past decades, such as prices and terms of payments that are agreed upon rather than being formed by markets. This situation leads to inefficient solutions in the use of capacity and working capital, and the transaction economy in Russia does not work like it works in the West.

According to this working capital analysis, the manufacturers seem to be in a stronger position compared with other actors in the supply chain. The analysis also implies that the supplier relationships in the Russian automotive industry are of a muscular type, where buyers use their negotiating power and dominant governance structure in a more captive than relational manner. 
Based on the present research findings, there are some practical implications that are relevant to organizations wishing to gain further value from their supply chain relations. First, a company's working capital model consists of three elements: inventory management, accounts receivable, and accounts payable. Instead of individually managing each component, companies should see working capital as a combination of these elements and pay attention to working capital as a whole. Of course, this study in the Russian context shows that especially practices surrounding payment terms differ from the ones that are typical in Western contexts, for example, by relying strongly on long payment terms toward suppliers at each stage of the supply chain. This structural specialty is not possible without some support from the actors outside the boundaries of the supply chain. Second, this study analyzes the companies' working capital models and places them into 27 categories based on their cycle times. It is difficult to name which models are the best, but the findings indicate that is not recommendable to apply the AAA model, where the cycle times of inventories and accounts receivable are short and the cycle time of accounts payable are long. The results support findings that profitable firms pay their suppliers promptly. Third, it seems that the sample companies do not follow any specific WCM strategy. The use of more deliberate strategies may optimize the governance structure of their supply chains, ultimately increasing profitability.

The benefits that accrue to firms that manage their working capital well are reflected in key performance areas such as liquidity, efficiency, profitability, and risk management. These different key performance areas require different strategies. Namely, profitability varies inversely with liquidity, and profitability moves together with risk. Risk related to business and return on investment seem to go hand in hand.

In conclusion, this study sheds light on using TCE by analyzing working capital that is tied up in different supply chain firms. The results imply that there are connections between uncertainty and the money that is tied up in working capital, particularly in inventory. To a certain extent, site specificity also explains cash conversation cycles. Hierarchies and captive relations are the dominant governance structures used in the Russian context.

This research reveals many important and relevant questions for future research. Future researchers should concentrate on a deeper analysis of relative power by using case studies focused on the actual supply chain of the automotive industry. Defining the structure of chain, the relationships of companies, and the volume of business between supply chain 
partners is particularly important. The role of regulators (e.g., political decision makers) in business ecosystem management and development should also be taken into consideration. It would be very interesting to extend the study into the upstream Russian value chain (the oil and iron industries) because companies that have to tolerate long payment times for credit do not belong to the supply chain analyzed in the present work. The results support the idea that the traditional doctrine related to the minimization of working capital is too black and white. Rather, there exist different contextual WCM strategies that are affected by different external and internal business ecosystem factors.

\section{Acknowledgements}

The authors would like to thank the Finnish Cultural Foundation for its financial support for Miia Pirttilä.

\section{References}

Association of European Businesses. (2018) Sales of cars and light commercial vehicles in December From: http://aebrus.ru/en/media/press-releases/

Blomqvist KM., Kyläheiko, K., and Virolainen, VM. (2002) Filling the Gap in Traditional Transaction Cost Economics: Towards Transaction Benefits based Analysis Using Finnish Telecommunications as an Illustration. International Journal of Production Economics, 79, $1-14$.

Brandenburg, M. (2016) 'Supply chain efficiency, value creation and the economic crisis An empirical assessment of the European automotive industry 2002-2010', International Journal of Production Economics, 171, pp.321-335.

Coase, R.H. (1937) The nature of the firm. Economica, 4, 386-405.

Deloof, M. (2003) Does working capital management affect profitability of Belgium firms?, Journal of Business Finance \& Accounting, 30, 573-587. 
Enqvist, J., Graham, M., Nikkinen, J. (2012). The impact of working capital management on firm profitability in different business cycles: Evidence from Finland, Research in International Business and Finance, 32, 36-49.

Ernst \& Young (2017) Overview of the Russian and CIS automotive industry. From: www.ey.com

Garfamy, R.,M. (2012) Supply Management: A Transaction Cost Economics Framework. South East European Journal of Economics and Business 7, (2).

Grover, V., \& Malhotra, M.K. (2003). Transaction cost framework in operations and supply chain management research: theory and measurement. Journal of Operations Management, $21,(4), 457-473$.

Haitham N., Jaya A., (2015) Current assets management of small enterprises, Journal of Economic Studies, 42, (4), 549-560.

FarrisII, M.T. and Hutchison, P.D. (2002) Cash-to-cash: the new supply chain management metric. International Journal of Physical Distribution \& Logistics Management, 32, 288298.

Gereffi, G., Humphrey, J. and Sturgeon, T. (2005) The Governance of Global Value Chains. Review of International Political Economy, 12, 78-104.

Hofmann, E., (2005). Supply Chain Finance: some conceptual insights. In: Lasch, R., Janker, C.G. (Eds.). Logistik Management - Innovative Logistikkonzepte. Wiesbaden, pp. 203-214. Jędrzejczak-Gas, J. (2017) Net Working Capital Management Strategies in the Construction Enterprises Listed on the NewConnect Market. Procedia Engineering, 182, 306-313.

Keith, B., Vitasek, K., Manrodt, J., and Kling, B. (2015) Strategic Outsourcing in New Economy. Palgrave MacMillan. 
Kristofik, P., Kok, J., de Vries, S., van Sten-van't Hoff, J. (2012) Financial Supply Chain Management - Challenges and Obstacles. ACRN Journal of Entrepreneurship Perspectives, $1,132-143$.

Lazaridis, I. and Tryfonidis, D. (2006) Relationship between working capital management and profitability of listed companies in the Athens stock exchange, Journal of Financial Management and Analysis, 19 (1), 26-35.

Lind, L., Pirttilä, M., Viskari, S., Schupp, F., Kärri, T. (2012) Working capital management in the automotive industry: Financial value chain analysis. Journal of Purchasing and Supply Management, 18, 92-100.

Lind, L., Monto, S. and Kärri, T. (2017) Categorizing working capital management practices in the automotive industry, 26th Annual IPSERA conference, April 9-12, Balatonfüred, Hungary.

Marttonen, S., Monto, S. and Kärri, T. (2013) Profitable working capital management in industrial maintenance companies, Journal of Quality in Maintenance Engineering, 19, (4), $429-446$.

Premkumar, G.P. (2000). Interorganization systems and supply chain management: An information processing perspective. Information Systems Management, 17 (3), 56-69.

Randall, W.S., Farris II, M.T. (2009) Supply chain financing: Using cash-to-cash variables to strengthen the supply chain. International Journal of Physical Distribution and Logistics Management, 39, 669-689.

Richards, V.D. and Laughlin, E.J. (1980) A cash conversion cycle approach to liquidity analysis, Financial Management, 9, pp. 32-38. 
Shin, H. and Soenen, L. (1998) Efficiency of working capital management and corporate profitability, Financial Practice and Education, 8, 37-45.

Virolainen, VM., Pirttilä, M., Hannola, L., and Kärri T. (2015) Power relations of the automotive industry value network. The 23rd International Conference on Production Research.

Volkswagen Group (2009) Driving ideas. Annual Report 2008.

Williamson, O.E. (1979) Transaction cost economics. The governance of contractual relations. Journal of Law and Economics, 22, 233-261.

Williamson, O.E. (1981) The economics of organization: The transaction cost approach. American Journal of Sociology, 87, 548-577.

Williamson, O.E. (2008) Outsourcing: Transaction cost economics and supply chain management. Journal of Supply Chain Management, 44, 5-16. 


\section{APPENDIX 1}

Wilcoxon Signed-Rank Test Statistics related to Table 2

\begin{tabular}{|l|r|r|}
\hline & $Z$ & Asymp. Sig. (2-tailed) \\
\hline Lind et al. (2017) 2006-2010: This study & -5.54 & .000 \\
\hline Lind et al. (2017) 2011-2015: This study & -4.183 & .000 \\
\hline Lind et al. (2012) 2006-2008: This study & -5.364 & .000 \\
\hline
\end{tabular}

\section{APPENDIX 2}

Wilcoxon Signed-Rank Test Statistics related to Figure 4

\begin{tabular}{|c|r|r|}
\hline & Z & Asymp. Sig. (2-tailed) \\
\hline DIO 2016-DIO 2013 & $-9.064^{\mathrm{b}}$ & .000 \\
\hline DIO 2015-DIO 2013 & $-10.150^{\mathrm{b}}$ & .000 \\
\hline DIO 2014-DIO 2013 & $-3.969^{\mathrm{b}}$ & .000 \\
\hline DSO 2016-DSO 2013 & $-11.475^{\mathrm{b}}$ & .000 \\
\hline DSO 2015-DSO 2013 & $-12.950^{\mathrm{b}}$ & .000 \\
\hline DSO 2014-DSO 2013 & $-6.672^{\mathrm{b}}$ & .000 \\
\hline DPO 2016-DPO 2013 & $-9.059^{\mathrm{b}}$ & .000 \\
\hline DPO 2015-DPO 2013 & $-9.795^{\mathrm{b}}$ & .000 \\
\hline DPO 2014-DPO 2013 & $-5.106^{\mathrm{b}}$ & .000 \\
\hline
\end{tabular}

b. Based on negative ranks 
